\section{Presentation to M. Marcellin Boule}

THE forthcoming retirement of the veteran anthropologist, M. Marcellin Boule, director of the Institut de Paleontologie humaine and professor of palæontology, after fifty years' service in the National Museum of Natural History, Paris, will be marked by the presentation to him of a medal by his friends and pupils as a token of admiration, gratitude and affection. M. Boule has long been recognized not merely as the leading authority in France on early man, but also as one of the very select few among anthropologists at large whose verdict on any matter under argument in prehistoric archæology and human palæontology comes as near finality as is possible in that ever-expanding field of science. Of his numerous contributions to the literature of his subject, "Les Hommes Fossiles" is as widely known as it is authoritative ; it will always stand as a record of conclusions based upon profound knowledge and painstaking research. The arrangements for the proposed honour to this distinguished man of science have been in the hands of a committee of which the Abbe Breuil, $\mathbf{P}$. Teilhard de Chardin, Prof. Verneau and other distinguished French anthropologists are members, and on which Great Britain is represented by Sir Arthur Smith Woodward and Prof. W. J. Sollas, Belgium by Prof. C. Fraipont, Holland by Dr. E. Dubois, and Switzerland by Prof. E. Pittard. A replica in bronze of the medal, which is the work of A. de Jaeger, will be presented to each subscriber to the fund, of which the secretaries are MM. J. Cottreau, J. Piveteau, H. Vallois and R. Vaufrey; treasurer, M. Georges Masson. The minimum amount of a contribution is 100 francs ; and it should be addressed, 120 boulevard Saint-Germain, Paris (vie).

\section{Recent Acquisitions at the British Museum (Natural History)}

Tне Department of Zoology has received as a permanent loan from His Majesty the King a mounted specimen of a cock scarlet-breasted parrakeet (Neophema splendida) which was formerly kept as a pet by His late Majesty King George V. This beautifully coloured bird, together with six other members of the same genus, is a native of Australia; it is now very rare, and the Museum possesses only a few examples. Two important collections have been acquired by the Department of Geology. One comprises a large series of Pleistocene and Quaternary mammals, chiefly from Clacton and the Lee Valley, collected over a series of many years by Mr. S. Hazzledine Warren, of Loughton, with special regard to their exact horizon and locality. The other acquisition consists of nearly two hundred type and figured specimens from the collection of Mr. J. W. Tutcher, of Bristol, of Jurassic invertebrate fossils, mostly Liassic ammonites from the Radstock dis. trict, described by the late Mr. S. S. Buckman. Mr. F. N. Ashcroft, who has long been a generous donor to the Mineral Department, has presented a further selection from his collection of Swiss minerals. The selection numbers about eighty-four specimens from twenty carefully recorded localities, and forms a valuable addition to the now extensive series of specimens from Switzerland in the Collection. The recent cliff fall between Newton and Yarmouth brought to light the existence in the Isle of Wight of gypsum. Mr. W. White has given the Museum one of the largest crystals that has been found. The most conspicuous of the purchases are a group of well-formed crystals of the beautiful emerald-green copper mineral, dioptase, from the French Congo, a magnificent group of prismatic crystals of celestine, and a large well-crystallized specimen of native copper.

\section{Prices of Biological Books in 1935}

THrs analysis of the cost of biological books in 1935 by John R. Miner (Quart. Rev. Biol., Dec. 1935) is the tenth of its kind, and allows of a comparison between the current prices and those of 1926, as well as between those of 1934 and 1935. The prices are quoted in cents per page and at the current rate of exchange into United States currency. The number of pages reviewed is 143,199 , an increase of 15.6 per cent over 1934 and 73.4 per cent over 1926. The cheapest of all publications are those of the U.S. Government, which are only 0.11 cents per page, a truly astounding figure which represents a reduction of 38.9 per cent on 1934 and 64.5 per cent on 1926 . The next cheapest are those of the British Govern. ment at 0.50 cents per page, a decrease of 43.8 per cent from 1934. It is pointed out that there has been a reduction of 25 per cent in the export price of German publications which, as it occurred late in 1935, does not come into the calculations. Against this is to be set the fact that from 1934 to 1935 there has been an increase of 7.9 per cent. Moreover, over the ten years there has been an increase of $87 \cdot 2$ per cent in the price of these works, so that Germany heads the list with an absolute price of 2.04 cents per page, or nearly twenty times that of the U.S. Government or two and a half times that of British non-Governmental publications. France started the decennium with the low price of 0.35 cents per page, and in spite of a drop of 14 per cent from 1934 has a total increase over the period of $145 \cdot 7$ per cent. The non-Governmental publications of Britain are 0.84 cents per page, of France 0.86 cents per page and of the United States 0.90 cents per page. In considering these statistics, it is to be borne in mind that they are not based upon the whole of the biological books published by the countries chosen but upon such samples as passed through the hands of the reviewer. They are not absolute, therefore, but they may be taken as giving some approximation to the actual conditions.

\section{National and International Health and Welfare}

VOLUNTARY associations providing maternity and child welfare services, under the Local Government Act, 1929, now receive annual contributions from the county or county borough council in whose area or for whose benefit they work. The Minister of Health has accordingly issued a circular (1538) reminding county and county borough councils 